\title{
The Production of Gaseous Biofuels Using Biomass Waste from Construction Sites in Recife, Brazil
}

\author{
Sergio Peres ${ }^{1, *} \mathbb{C}$, Eduardo Loureiro $\left.{ }^{2} \mathbb{(}\right)$, Humberto Santos ${ }^{2}$, Fabio Vanderley e Silva ${ }^{3}$ and \\ Alexandre Gusmao ${ }^{3}$ \\ 1 Master's Program on Energy System, Mechanical Engineering Department, Universidade de Pernambuco, \\ Recife 50720-001, Brazil \\ 2 Mechanical Engineering Department, Universidade de Pernambuco, Recife 50720-001, Brazil; \\ eduardoloureiro@poli.br (E.L.); humberto.s.santos@hotmail.com (H.S.) \\ 3 Master's Program on Civil Engineering, Civil Engineering Department, Universidade de Pernambuco, \\ Recife 50720-001, Brazil; fabiomarcelo@compesa.com.br (F.V.eS.); gusmao.alex@ig.com.br (A.G.) \\ * Correspondence: sergperes@gmail.com or speres@poli.br; Tel.: +55-81-98823-1380
}

Received: 28 December 2019; Accepted: 17 March 2020; Published: 13 April 2020

\begin{abstract}
Due to climate change problems caused by greenhouse gas emissions generated by fossil fuels and from waste disposition, fuel alternatives for power generation are being extensively researched. Currently, in Brazil and in many countries, wood waste is disposed in landfills. However, due to lignin, one of the major constituents of biomass, which prevents wood waste from suffering microbial degradation, there is no significant mass degradation, even over decades, when landfilled. Hence, landfilling is not a solution to discard wood waste. Hence, one of the solutions to get rid of the great amount of wood waste is to use it as feedstock in waste-to-electricity (WTE) projects. WTE projects are in high demand in the world, as they can replace fossil fuels and they reduce two major environmental problems (greenhouse gas emissions due to the use of fossil fuels and the accumulation of waste in landfills), while generating biofuels and/or electricity. One of the residues that can be used in WTE projects is biomass residue from construction sites (CCbiowaste). CCbiowaste could be converted into gaseous biofuels through pyrolysis or gasification. These gaseous biofuels can be used in Otto engines connected to an electricity generator (gensets) to produce electricity and/or heat (cogeneration applications). Hence, the objective of this research was to characterize (physically, chemically, and energetically) civil construction biomass wastes (CCbiowaste), produced in a residential building construction site in Recife, Brazil, and to use these wastes in a bench-scale gasifier to produce gaseous biofuels at the temperatures of $700{ }^{\circ} \mathrm{C}, 800{ }^{\circ} \mathrm{C}$, and $900{ }^{\circ} \mathrm{C}$. The gaseous fuels were collected in the gasifier and analyzed in a gas chromatograph equipped with a thermal conductivity detector (TCD) to determine their composition and heating values. The lower heating value (LHV) results varied from $8.07 \mathrm{MJ} \cdot \mathrm{m}^{-3}$ to $10.74 \mathrm{MJ} \cdot \mathrm{m}^{-3}$ for $700{ }^{\circ} \mathrm{C}$ to $900{ }^{\circ} \mathrm{C}$ gasification temperature. These gaseous fuels were tested in an adapted Otto cycle engine connected to an electricity generator to prove the feasibility of this application. The highest total energy per ton of biomass was obtained for mixed wood and Pinus at $900{ }^{\circ} \mathrm{C}$, with approximately $13 \mathrm{GJ} \cdot$ ton $^{-1}$. Hence, the use of CCbiowaste can become an option for the reuse of wasted wood instead of simply dumping in a landfill.
\end{abstract}

Keywords: CCbiowaste; gasification; WTE; gaseous biofuels

\section{Introduction}

Brazil became an emergent country in the last decade and its development mainly involved infrastructure (refinery, car industry) and habitational projects. These sites have a great impact on 
the environment due to fact that some of the waste generated during construction (CCbiowaste) is dumped in landfills with little recycling, especially biomass (plywood, timber, wood poles, cement bags, and sawed biomass) [1]. According to Vanderlei e Silva (2013), there are approximately 200 tons of biomass waste generated daily in Recife, Brazil. In Brazil, most of this biomass waste generated in civil construction sites is dumped in landfills or in inappropriate places (open dumps, left at the construction sites, or even left in the streets). According to Ximenes et al. (2015), prior to 2008, $1,457,000$ tons of wood waste was deposited in Australia annually. Approximately $70 \%$ of the wood waste was generated in the construction and demolition (C\&D) and/or commercial and industrial (C\&I) streams [2]. In Europe, all wood waste must be used either in construction as recycled wood or in boilers and in municipal waste incinerators as biofuel, since the disposal of any wood waste in landfills is prohibited [3]. According to Diyamandoglu and Fortuna, 170 million tons of C\&D waste was generated in the United States in 2003. Forty-eight percent (48\%) of this total was dumped in landfills. Wood represented $33 \%$ of this total, i.e., approximately 30 million tons of wood was disposed of in landfills [4]. Wang et al. (2011) observed carbon loss varying from $0 \%$ up to $7.8 \%$ in hardwood such as red oak and Eucalyptus pilularis samples, and in softwood such as spruce and radiata pine from Australia in laboratory experiments [5]. Ximenes et al. concluded that there was little or no sign of decay in the wood samples analyzed from the landfill in Sydney, even in samples extracted from landfills that were 46 years old $[2,6]$. As a result of this investigation, it was concluded that the biodegradation of wood waste or CCbiowaste in landfills is very low or insignificant $[2,5,6]$.

Cellulose, hemicellulose, and lignin are the major building blocks of lignocellulosic materials or wood biomass. Their percentage varies based on the type of biomass. Cellulose is the most abundant polymer, which corresponds to $20-30 \%$ of the primary cell wall's dry mass. Hemicellulose is the other major polysaccharide after cellulose, which corresponds to $20-40 \%$ by mass of lignocellulosic materials [7]; it is the third major component, which corresponds to $30 \%$ by mass of the cell wall and contributes up to $40 \%$ of the energy content [7]. Lignin is the cementing agent for cellulose fibers, holding adjacent cells together [8]. According to Khan and Ahring (2019) and Buendia-Kandia et al., lignin is an important constituent of the cell wall as it provides structural support and prevents microbial attacks and decomposition of the cell wall [7-9]. For this reason, CCbiowaste is not easily degraded by microorganisms in landfills, and, for this reason, environmentally friendly technological routes ought to be found to use this wood waste as a large-scale feedstock.

The most challenging issue in civil construction, in Brazil, as well as in other parts of the world, is to implement sustainable practices and to have an ecofriendly large-scale use of this biomass that can no longer be reused in construction sites due to its physical condition (damaged or broken) or if there is no other construction site to be used, as dumping in landfills was proven to not be a correct solution.

One alternative for the valorization of biomass waste is its use as a feedstock for waste-to-energy technology (WTE). WTE is defined as the process of recovering energy in the form of electricity and/or heat, as well as in the form of biofuels, by using thermal or biological processes $[2,9,10]$. One of the WTE routes is to use thermochemical processes to convert solid or liquid feedstock into gaseous fuels through gasification, pyrolysis, or hydrothermal liquefaction; the other routes consist of either biological processes comprising anaerobic digestion and alcoholic fermentation or landfilling with biogas recovery [9-11]. All routes convert solid biomass into biofuels. According to Passos et al., incineration is a treatment process that involves the combustion of waste. It can be used for electricity generation or to supply heat. However, due to the pollution control cost and the environmental danger it may represent, incineration has a low acceptance in the society [10].

The moisture content of feedstocks is one of the keys to selecting a proper route. Generally, low-moisture-content biomass is more feasible for use in the gasification and pyrolysis routes, while high-moisture-content biomass may be used as a feedstock for biological and hydrothermal liquefaction [2,3,9-11]. Hydrothermal liquefaction is normally carried out at $280-370^{\circ} \mathrm{C}$, between $10 \mathrm{MPa}$ and $25 \mathrm{MPa}$, and its main products are biocrude oil with a heating value ranging between 22.8 and $36 \mathrm{MJ} \cdot \mathrm{kg}^{-1}$, char, water-soluble substances, and gas [11]. According to Toor et al., hydrothermal 
liquefaction processes have the potential to become an important technology for converting wet biomass or organic waste into bio-oil for fuel and other applications [11]. Hence, due to their lower moisture content, civil construction biomass residues (CCbiowaste) were used as a feedstock in a bench-scale air gasifier to produce gaseous fuels. In the majority of cases, thermal chemical conversions require appropriate pre-treatments like drying, milling, and separation for efficient conversion [10]. In air gasification, biomass is partially oxidized to produced gaseous fuels $[2,10,12]$. For gasification processes, the temperature range lies within $700{ }^{\circ} \mathrm{C}$ and $900{ }^{\circ} \mathrm{C}$ in oxygen-deprived environments, typically $25-35 \%$ of the stoichiometric ratio for complete combustion [10]. The gaseous fuels' main constituents are carbon monoxide $(\mathrm{CO})$, carbon dioxide $\left(\mathrm{CO}_{2}\right)$, hydrogen $\left(\mathrm{H}_{2}\right)$, methane $\left(\mathrm{CH}_{4}\right)$, nitrogen $\left(\mathrm{N}_{2}\right)$, and hydrocarbons (HCs) $[2,10,12-17]$. The lower calorific value of these gaseous fuels may vary from 4-13 MJ. $\mathrm{m}^{-3}$ depending on the gasifier temperature and type [10,12-17]. According to Sikarwar et al. (2016), one of the most commonly used gasifiers is a fixed-bed gasifier (FXBG) that can exist as either an updraft (fuel enters from the top, gasifying agent enters from the bottom) or a downdraft gasifier (both fuel and gasifying agent enter from the top) [17]. Gasification enables solid biomass to be used as fuel in internal combustion engines and gas turbine cycles, as well as to produce green liquid fuels [9,11-17]. Kirubakaran et al. reported that gasification is economical at all capacities from $5 \mathrm{kWe}$ onward, and that the rate of gasification is affected by the size, shape, environment, moisture, and ash content of the feedstock, as well as waste flow (batch or continuous) and gasification temperature [18]. For this reason, it is necessary to determine several characteristics of the biomass feedstock prior to the gasification process. The main characteristics to be determined are moisture, volatile matter, fixed carbon content, and ash content, which were obtained through proximate or thermogravimetric analysis (TGA). Furthermore, the effect of temperature and heating rate on biomass weight loss can be analyzed through TGA [18]. Ultimate analysis determines the amount of carbon, hydrogen, nitrogen, oxygen, and sulfur present in the solid biomass. The amount of bio-oxygen helps to convert solid combustible matter into gaseous fuels. Moreover, gasification can be catalyzed by certain metals contained in the ash. Gasification by bio-oxygen in the presence of ash is called auto-gasification [18]. These data obtained are important when analyzing the heat content of CCbiowaste. It is important to mention that gasification technology can use a wide range of feedstocks such as wood, crop residues, peat, black liquor, waste, and so forth. This process can be applied for the production of heat, electricity, and chemical energy, as well as transport fuels [8,11,18-20].

All CCbiowaste characterization and gasification experiments were carried out at the Fuel and Energy Laboratory of the University of Pernambuco, in Recife, Brazil.

The importance of this work lies in the fact that few researchers investigated the gasification of CCbiowaste or landfill-diverted wood. According to Littlejonhs et al. (2020), many experimental gasification studies focused on the utilization of clean wood chips, and there is a lack of experimental gasification studies using more challenging feedstocks such as landfill-diverted feedstock or CCbiowaste [19]. Hence, the use of wood waste as a feedstock for distributed biomass gasification cogeneration provides an economical solution to avoid landfilling whilst producing low-carbon energy [19].

As an incentive to produce electricity from renewable sources, starting on 1 March 2018, through Decree 65 of the Ministry of Mines and Energy, the Brazilian Government established a new tariff when purchasing electricity in the decentralized power generation program, called ProGD. The price for MWh generated using residual biomass was R $\$ 349.00$ (Brazilian real) and that for municipal solid waste was $\mathrm{R} \$ 561.00$ [21,22]. For comparison reasons, it is worth nothing that the exchange rate was $\$ 1$ United States dollar (USD) to R $\$ 4.0805$ on 25 December 2019 [23].

This work had the objective of promoting the use of CCbiowaste as fuel, avoiding environmental problems such as the accumulation of CCbiowaste in landfills due to its low biodegradability. Furthermore, this work obtained the physical, chemical, and energetic data for CCbiowaste, as these properties can help understand the thermo-chemical conversion of solid biomass waste to gaseous fuels through gasification, as well as evaluate their potential to generate electricity in civil construction sites. 


\section{Materials and Methods}

This work was based on collecting biowaste samples in civil construction sites in Recife during the construction of a multi-story residential building made of reinforced concrete and masonry, consisting of 40 floors and a constructed area of 11,416.91 $\mathrm{m}^{2}$. Reinforced concrete and masonry are the most common type of building construction carried out in Brazil [24].

\subsection{CCbiowaste Characterization}

A compositional analysis of the biomass waste produced in the construction site was carried out using the Brazilian Standard ABNT NBR 10.007:2004 [25]. Furthermore, it was observed that the biomass used in several phases of the building construction could be divided into four main groups: mixed wood (timber made of several types of wood such as eucalyptus, cedar, and Pinus, for instance; the composition is not fixed, as other types of wood can be used), Pinus (Pinus elliotti), plastic-coated plywood, and resin-coated plywood.

The collected biomass samples were physically treated to obtain their physical, chemical, and energetic data, before being used as a feedstock in the gasifier. The physical treatment consisted of grinding, screening, homogenizing, and manually densifying to form pellets. For grinding, a knife mill made by Marconi (Marconi Equipamentos para Laboratorio, Piracicaba-SP, Brazil -marconi@marconi.com.br), Model MA-048 was used with a screen Mesh 20/30 (0.841-0.595 mm). The ground biomass was densified using a manual press ( IKA Werke GmbH, Janke-Kunkel Strasse 10, Staufen im Breisgau, Germany), and the pellets were used in analytical equipment to obtain their data; for the gasification experiments, the pellets were made using a $100-\mathrm{kg} \cdot \mathrm{h}^{-1}$ pelletizer manufactured by Xuzhou Orient Industry Co. Ltd. (Xuzhou - Jiangsu, China).

The experiments to obtain the physical, chemical, and energetic data of the biomass waste were carried out at the Fuel and Energy Laboratory of the University of Pernambuco, in Recife, Brazil. The experiments and the standards used were as follows: density (ABNT NBR 7190, 1997 [26]); moisture content-dry-oven method (ABNT NBR 14929, 2017 [27] and ASTM D 4442-07 [28]); ultimate analysis (ASTM D3176-15 [29]); proximate analysis (ASTM D 3172-12 [30]); ash content (ABNT NBR 8289 [31] and ASTM D 2974-87 [32]); higher and lower heating values (ASTM D 2015-77, 1983 [33]).

For ultimate analysis, the Elemental-Vario-El Cube equipment (Elementar Analysensysteme $\mathrm{GmbH}$, Langenselbold, Germany) was used to determine the carbon, hydrogen, oxygen, nitrogen, and sulfur content, in $\% \mathrm{~m} / \mathrm{m}$, of the biomass waste. For approximate analysis, the moisture, as well as the volatile, fixed carbon, and ash content, was determined using a Shimadzu-model DTG-60 (Shimadzu Corporation, Kyoto, Japan). For these experiments, the thermogravimetric balance was set to heat from ambient temperature $\left(30^{\circ} \mathrm{C}\right)$ to $900^{\circ} \mathrm{C}$, using a fixed heating ramp of $10^{\circ} \mathrm{C} \cdot \mathrm{min}^{-1}$. From ambient temperature to $850^{\circ} \mathrm{C}$, nitrogen was used as the oven atmosphere to obtain moisture and volatile mass data; then, the oven atmosphere was changed to oxygen, a reactive gas, to burn the fixed carbon and to obtain the ash content of the biomass. An IKA C-2000 calorimeter (IKA Werke $\mathrm{GmbH}$, Staufen im Breisgau, Germany) was used for determining the biomass samples' higher heating value (HHV) and lower heating value (LHV).

\subsection{Gasification Experiments}

The gasification experiments were carried out using a bench-scale gasifier (BSG), illustrated in Figure 1. This BSG in the experiments was designed by Peres [14] and implemented with monitoring equipment for operation at different gasification temperatures and residence times [34,35]. This BSG consisted of a 30-cm-long, two-inch-diameter, 304 stainless-steel seamless tube gasifier (1). The reactor internal temperature distribution was monitored using three type $\mathrm{K}$ thermocouples (2). The bench-scale gasifier was heated externally by two electrical resistors (1000 W total) (3) and thermally isolated with a 2-mm-thick flexible rockwool insulation blanket (4). At one end of the gasifier tube, there was a ball valve (5) where the biomass samples could be placed in the middle of the reactor and the 
gasification residues could be removed. On the other end, a needle valve (6) and a pressure gauge (7) were installed. The pressure gauge was used to monitor the pressure increase during the gasification process, and, when there was no increase in pressure, it was assumed that the conversion of solid to gas was complete. Then, after the established residence time ( $3 \mathrm{~min})$, the needle valve was opened, and the biomass gaseous fuels, after passing through a filter made of oxidized steel wool (not shown in Figure 1), used as a heat sink to remove condensables, were collected in sample bags through the port (8). All experiments were carried out in batch mode in limited aerobic conditions, as only the air trapped inside the reactor was used in the gasification experiments.

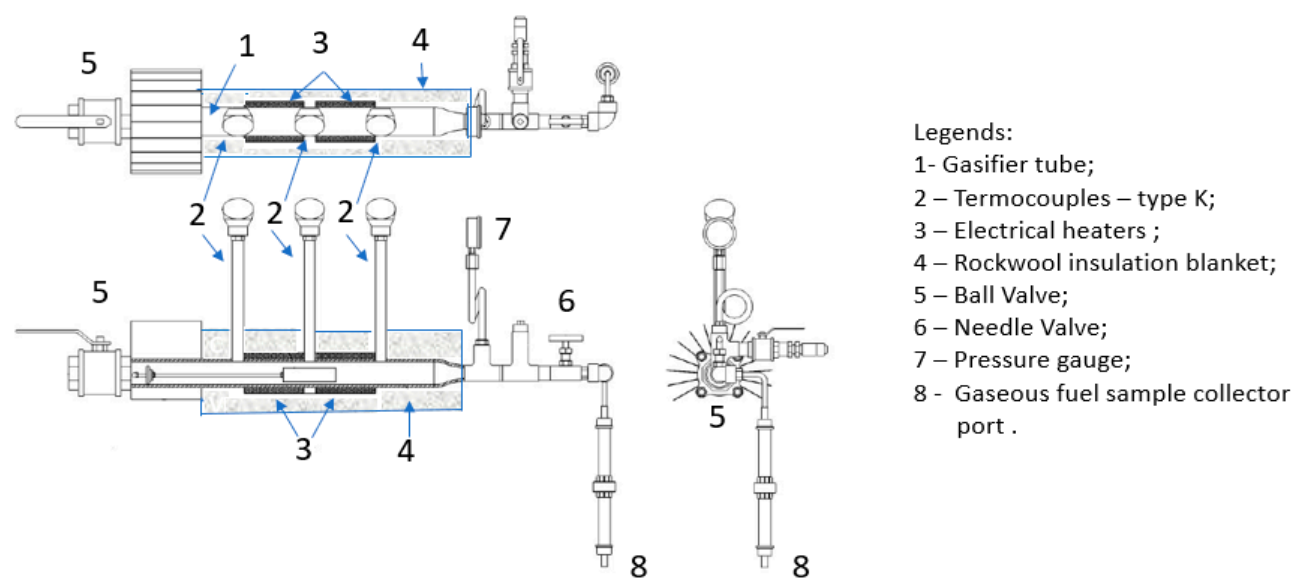

Figure 1. The POLICOM bench-scale gasifier scheme (adapted from Reference [34]).

The air gasification experiments were conducted at $700{ }^{\circ} \mathrm{C}, 800{ }^{\circ} \mathrm{C}$, and $900{ }^{\circ} \mathrm{C}$ using a 3-min residence time, with samples weighing $5 \mathrm{~g}$, as done in the work of Geraldo (2012), Vanderlei e Silva (2014), and Cavalcanti (2017) [1,34,35]. The gaseous fuel content at the given temperatures was analyzed by gas chromatography using a GC SRI-8610C (SRI Instruments, Torrance, CA, USA), equipped with a thermal conductivity detector (TCD). The carrier gases were argon and hydrogen. Hydrogen gas was used for the analysis of all gases except for hydrogen, which was analyzed using argon as the carrier gas. After the determination of the gases produced and their volume, it was possible to work out the volume, gaseous content, and calorific value of gas produced in each experiment at the given temperatures. This procedure was described in Peres (1997) [14].

\section{Results and Discussion}

In this section, the results are divided into biomass collection and sampling, biomass characterization, and gasification.

\subsection{Biomass Collection and Sampling}

This first step was to analyze the construction site documents to determine the amount of biomass purchased to construct the multi-story residential building. The results are shown in Table 1.

Table 1. Total purchased biomass for the residential building construction site.

\begin{tabular}{lcc}
\hline \multicolumn{1}{c}{ Biomass Type } & Mass (ton) * & Mass Percentage (\%) \\
\hline Mixed wood & 110 & 67 \\
Pinus & 18 & 11 \\
Plastic-coated plywood & 24 & 14 \\
Resin-coated plywood & 12 & 8 \\
\hline Total & 164 & 100 \\
\hline \multicolumn{2}{c}{ * Total biomass mass (on a wet basis). }
\end{tabular}

* Total biomass mass (on a wet basis). 
As observed in Table 1, mixed wood was the most acquired biomass for the construction site. The mixed wood consisted of different types of woods, with no specification of type given by the seller. Mixed wood is used for the construction of concrete mold, scaffolding timbers, slats, and rafters. In Brazil, generally, there are 18 types of woody biomass used for this purpose. The complete list of wood used in construction sites in Brazil can be seen in the work by Zenid (2009) [36]. Examples of types of wood used in Brazil are Hymenolobium spp., Platonia insignis, Erisma uncinatum, Eucalyptus tereticornis, E. citriodora, E. saligna, and Clophyllum brasiliense [36]. According to Mello and Vieira (2015), CCbiowaste represents $31 \%$ to $42 \%$ by volume or $25 \%$ to $35 \%$ by mass of the waste generated in the construction of residential buildings in Brazil [37]. Due to the large number of types of wood used in civil construction, details on the most common wood type used in building constructions were not found in the literature, as the availability of the different types varies significantly in Brazil and in the world. For this reason, the quantity of wood, shown in Table 1, was determined using a booklog of residues of the studied residential building construction site. This log took into account that most of the biomass was relocated to other construction sites or sold to recycling companies to be used at other construction sites (by other companies) or as fuel for bakeries and pizzerias [1].

\subsection{Biomass Characterization}

\subsubsection{Density, Moisture, and Ash Content}

The results of density, moisture, and ash content, on a dry basis and in terms of $\% \mathrm{~m} / \mathrm{m}$, of the construction site biomass waste are shown in Table 2. As observed, the highest density was found for mixed biomass at $800 \mathrm{~kg} \cdot \mathrm{m}^{-3}$, while that for Pinus was $414 \mathrm{~kg} \cdot \mathrm{m}^{-3}$. For the two types of plywood, the densities were about the same, at around $520 \mathrm{~kg} \cdot \mathrm{m}^{-3}$.

Table 2. Density, moisture, and ash content by mass.

\begin{tabular}{|c|c|c|c|}
\hline Biomass Type & $\begin{array}{c}\text { Density } \\
\left(\mathrm{kg} \cdot \mathrm{m}^{-3}\right) *\end{array}$ & $\begin{array}{c}\text { Moisture } \\
(\%) *\end{array}$ & $\begin{array}{l}\operatorname{Ash}^{2}(\%) \\
\left(600^{\circ} \mathrm{C}\right) *\end{array}$ \\
\hline Mixed wood & $800 \pm 12$ & $7.6 \pm 0.1$ & $1.08 \pm 0.07$ \\
\hline Pinus & $414 \pm 21$ & $7.4 \pm 0.1$ & $0.94 \pm 0.01$ \\
\hline Plastic-coated plywood & $519 \pm 17$ & $10.3 \pm 0.1$ & $2.09 \pm 0.10$ \\
\hline Resin-coated plywood & $521 \pm 3$ & $9.2 \pm 0.1$ & $2.11 \pm 0.12$ \\
\hline Weighted average $^{3}$ & 696 & 8.1 & 1.29 \\
\hline
\end{tabular}

The moisture content varied from $7.6 \%$ to $10.3 \%$, by mass, with no prior drying process. The ash content varied from $0.94 \%$ to $2.11 \%$, by mass.

The Wood Fuels Handbook states that the density of Pinus and plywood lies within the bulk density of beech, spruce, and fir, ranging from $445 \mathrm{~kg} \cdot \mathrm{m}^{-3}$ to $304 \mathrm{~kg} \cdot \mathrm{m}^{-3}$ [38]. Furthermore, the density of conifer wood such as cypress, stone pine, maritime pine, and Aleppo pine varies from $600 \mathrm{~kg} \cdot \mathrm{m}^{-3}$ to $810 \mathrm{~kg} \cdot \mathrm{m}^{-3}$ [38]. Wood ash content may vary from $0.20 \%$ to $6.13 \%$ by mass; however, the ash content can be much higher for agriculture residues such as sugarcane bagasse and rice hulls, with $13.30 \%$ and $15.41-20.60 \%$ by mass, respectively $[13,14,19,38-41]$. Moisture contents of $6.5 \%$ and $14.1 \%$ (as received) were reported for Eucalyptus [38,42], while values of $0.4 \%$ and $0.3 \%$ were obtained for air-dried spruce and pine, respectively [18]. Additionally, the moisture content was found to vary from $3.03 \%$ to $8.65 \%$, by mass, for willow, poplar, maritime pine, and chestnut [39]. However, Littlejohns et al., who used landfill-derived wood waste, reported moisture contents of $10 \%$ to $11 \%$ and $7 \%$ to $8 \%$ for air-dried spruce and pine, respectively, while moisture contents of $6 \%$ and $20 \%$ were obtained for construction and demolition (C\&D) wood. The ash content for C\&D wood varied from $0.7 \%$ to $0.8 \%$, by mass, as received [19]. According to Basu (2010) and Ruiz et al. (2013), thermal gasification typically requires a moisture content of less than $15 \%$ [8,13]. Every kilogram of moisture needs about $2300 \mathrm{~kJ}$ of heat to 
vaporize and an additional $1500 \mathrm{~kJ}$ to be raised to a typical gasifier temperature of $700{ }^{\circ} \mathrm{C}$. Therefore, lower moisture results in more heat available in the product gas [8]. Hence, it is desirable to keep moisture as low as possible to enhance the gaseous product heating value.

\subsubsection{Ultimate Analysis}

The biomass composition in terms of carbon, hydrogen, nitrogen, sulfur, and oxygen was determined as shown in Table 3.

Table 3. Ultimate analysis results.

\begin{tabular}{|c|c|c|c|c|c|}
\hline \multirow[t]{2}{*}{ Biomass Type } & \multicolumn{5}{|c|}{ Content (\% by mass) * } \\
\hline & $\mathrm{C}$ & $\mathbf{H}$ & $\mathbf{O}$ & $\mathbf{N}$ & $\mathrm{S}$ \\
\hline Mixed wood & $46.27 \pm 0.55$ & $6.59 \pm 0.03$ & $45.67 \pm 0.56$ & $0.16 \pm 0.01$ & $0.21 \pm 0.02$ \\
\hline Pinus & $46.29 \pm 0.19$ & $6.58 \pm 0.03$ & $46.32 \pm 0.22$ & $0.10 \pm 0.01$ & $0.11 \pm 0.01$ \\
\hline Plastic-coated plywood & $48.08 \pm 1.03$ & $6.57 \pm 0.13$ & $43.72 \pm 1.17$ & $0.24 \pm 0.01$ & $0.10 \pm 0.01$ \\
\hline Resin-coated plywood & $47.60 \pm 0.50$ & $6.56 \pm 0.08$ & $44.04 \pm 0.59$ & $0.21 \pm 0.01$ & $0.11 \pm 0.01$ \\
\hline Weighted average ${ }^{1}$ & 46.63 & 6.58 & 45.34 & 0.17 & 0.18 \\
\hline
\end{tabular}

According to the Wood Fuels Handbook and the Atlas of Thermal Data, the typical values for coniferous wood ultimate analysis, by mass, are as follows: C (47-54\%), H (5.6-7.0\%), O (40-44\%), $\mathrm{N}(0.1-0.5 \%)$, and S (0.01-0.05\%) [34,38]. For woody energy crops such as Eucalyptus and Casuarina, the results are as follows: C (48.5-49\%), H (5.83-6.04\%), O (43.32-45.13\%), N (0.15-0.59\%), and S $(0.30-0.59 \%)$ [39]. Similar results for the ultimate analysis of C\&D wood waste were reported for woody biomass by other authors [19,39-43].

\subsubsection{Proximate Analysis}

The proximate analysis results are shown in Table 4.

Table 4. Proximate analysis results.

\begin{tabular}{lcccc}
\hline \multirow{2}{*}{ Biomass Type } & \multicolumn{4}{c}{ Content $(\%$ by mass) } \\
\cline { 2 - 5 } & Volatiles & Fixed carbon & Ashes $^{*}\left(\mathbf{9 0 0}{ }^{\circ} \mathbf{C}\right)$ & Moisture $^{*}$ \\
\hline Mixed wood & $98.59 \pm 0.19$ & $0.53 \pm 0.11$ & $0.88 \pm 0.11$ & $11.35 \pm 0.32$ \\
Pinus & $98.68 \pm 0.04$ & $0.50 \pm 0.03$ & $0.82 \pm 0.06$ & $13.68 \pm 0.34$ \\
Plastic-coated plywood & $99.42 \pm 0.13$ & $0.41 \pm 0.07$ & $0.17 \pm 0.03$ & $11.88 \pm 0.78$ \\
Resin-coated plywood & $99.4 \pm 0.16$ & $0.34 \pm 0.05$ & $0.26 \pm 0.07$ & $12.78 \pm 0.22$ \\
\hline Weighted average $^{1}$ & 98.78 & 0.49 & 0.72 & 11.79 \\
\hline
\end{tabular}

${ }^{*}$ On a dry basis; ${ }^{1}$ based on the percentage of each type of biomass (Table 1 ).

Several authors reported values for the proximate analysis of woody biomass as follows: volatiles $(67.92-90.60 \%)$ and fixed carbon $(9.20-23.01 \%)$, by mass [36-43]. These values were smaller than those obtained in this research, probably due to different test conditions, especially the temperature range. In this research, the heat ramp was set to $10^{\circ} \mathrm{C} \cdot \mathrm{min}^{-1}$, and the inert nitrogen atmosphere was changed to an oxygen atmosphere at $850{ }^{\circ} \mathrm{C}$, while the experiment finished at $900{ }^{\circ} \mathrm{C}$. Some authors carried out their experiments in temperatures up to $660^{\circ} \mathrm{C}[39,43]$ and $280^{\circ} \mathrm{C}$ [40], or using the oven-dry method [38]. For this reason, the ash results reported in Table 4 were lower than those found in the literature [38-44]. 


\subsubsection{Calorimetric Analysis}

The higher heating value (HHV) and lower heating value (LHV) for each type of biomass used in the construction site are illustrated in Table 5.

Table 5. Biomass higher heating value (HHV) and lower heating value (LHV).

\begin{tabular}{|c|c|c|}
\hline Biomass Type & $\mathrm{HHV} *\left(\mathrm{MJ} \cdot \mathrm{kg}^{-1}\right)$ & $\mathrm{LHV}^{*}\left(\mathrm{MJ} \cdot \mathrm{kg}^{-1}\right)$ \\
\hline Mixed wood & $18.205 \pm 97$ & $17.988 \pm 113$ \\
\hline Pinus & $17.701 \pm 153$ & $17.509 \pm 172$ \\
\hline Plastic-coated plywood & $17.723 \pm 101$ & $17.487 \pm 124$ \\
\hline Resin-coated plywood & $17.804 \pm 84$ & $17.560 \pm 88$ \\
\hline Weighted average ${ }^{1}$ & 18.050 & 17.831 \\
\hline
\end{tabular}

The HHV for Pinus was 5\% lower than that reported by Pintor-Ibarra et al. (2017) [44], with similar results obtained by other authors $[19,39,43]$. However, as a whole, the values in Table 5 were within the values of 13.3 to $19.2 \mathrm{MJ} \cdot \mathrm{kg}^{-1}$ reported in the literature for different biomass [19,35-45].

The higher energy content of biomass, lower ash content, and higher content of hydrogen and oxygen, combined with the high volatile matter, indicate that the biomass can be easily converted to gaseous fuel and it can combust more easily than coal, for instance [43].

\subsection{Biomass Waste Gasification}

The gaseous formation results are shown in Table 6, Table 7, and Table 8 for the $700{ }^{\circ} \mathrm{C}, 800{ }^{\circ} \mathrm{C}$, and $900{ }^{\circ} \mathrm{C}$ gasification experiments, respectively. The bench-scale gasification experiment investigated the effect of reactor temperature on the gaseous fuels formed for each type of biomass used from the construction site.

Table 6. Gaseous fuel composition for the $700{ }^{\circ} \mathrm{C}$ gasification.

\begin{tabular}{|c|c|c|c|c|c|c|}
\hline \multirow[t]{2}{*}{ Biomass Type } & \multicolumn{5}{|c|}{ (\% mol/mol) } & \multirow{2}{*}{$\begin{array}{c}\text { LHV } \\
\left(\mathrm{MJ} \cdot \mathrm{m}^{-3}\right)\end{array}$} \\
\hline & $\mathrm{H}_{2}$ & $\mathrm{CO}$ & $\mathrm{CO}_{2}$ & $\mathrm{CH}_{4}$ & $\mathbf{N}_{2}$ & \\
\hline Mixed wood & $25.2 \pm 0.8$ & $13.1 \pm 1.3$ & $27.5 \pm 1.2$ & $11.7 \pm 0.1$ & $21.8 \pm 1.3$ & $8.07 \pm 0.15$ \\
\hline Pinus & $22.5 \pm 2.2$ & $14.1 \pm 1.0$ & $28.1 \pm 0.9$ & $13.9 \pm 0.3$ & $20.0 \pm 1.0$ & $8.99 \pm 0.47$ \\
\hline Plastic-coated plywood & $24.1 \pm 1.5$ & $11.7 \pm 0.2$ & $28.4 \pm 0.5$ & $13.3 \pm 0.7$ & $21.3 \pm 0.3$ & $8.55 \pm 0.22$ \\
\hline Resin-coated plywood & $22.8 \pm 2.0$ & $12.4 \pm 0.9$ & $27.2 \pm 2.0$ & $13.3 \pm 0.9$ & $23.1 \pm 1.9$ & $8.53 \pm 0.41$ \\
\hline Weighted average ${ }^{1}$ & $24.6 \pm 1.1$ & $13.0 \pm 0.9$ & $27.6 \pm 0.5$ & $12.3 \pm 0.8$ & $21.6 \pm 1.1$ & $8.28 \pm 0.35$ \\
\hline
\end{tabular}

Table 7. Gaseous fuel composition for the $800{ }^{\circ} \mathrm{C}$ gasification.

\begin{tabular}{|c|c|c|c|c|c|c|}
\hline \multirow[t]{2}{*}{ Biomass Type } & \multicolumn{5}{|c|}{ (\% mol/mol) } & \multirow{2}{*}{$\begin{array}{c}\text { LHV } \\
\left(\mathrm{MJ} \cdot \mathrm{m}^{-3}\right)\end{array}$} \\
\hline & $\mathbf{H}_{2}$ & $\mathrm{CO}$ & $\mathrm{CO}_{2}$ & $\mathrm{CH}_{4}$ & $\mathbf{N}_{2}$ & \\
\hline Mixed wood & $25.4 \pm 2.4$ & $14.9 \pm 0.6$ & $31.1 \pm 2.0$ & $14.8 \pm 0.3$ & $12.3 \pm 1.0$ & $9.72 \pm 0.43$ \\
\hline Pinus & $21.8 \pm 1.7$ & $15.9 \pm 0.3$ & $31.9 \pm 2.4$ & $16.8 \pm 1.6$ & $12.0 \pm 0.8$ & $10.18 \pm 0.68$ \\
\hline Plastic-coated plywood & $31.5 \pm 0.4$ & $13.4 \pm 0.5$ & $25.8 \pm 2.4$ & $16.1 \pm 0.3$ & $11.4 \pm 0.9$ & $10.70 \pm 0.11$ \\
\hline Resin-coated plywood & $30.2 \pm 2.3$ & $14.5 \pm 1.3$ & $24.1 \pm 2.4$ & $15.5 \pm 0.3$ & $14.3 \pm 0.8$ & $10.28 \pm 0.40$ \\
\hline Weighted average ${ }^{1}$ & $26.2 \pm 3.9$ & $14.7 \pm 0.9$ & $29.9 \pm 3.3$ & $15.3 \pm 0.7$ & $12.3 \pm 1.1$ & $9.95 \pm 0.39$ \\
\hline
\end{tabular}


Table 8. Gaseous fuel composition for the $900{ }^{\circ} \mathrm{C}$ gasification.

\begin{tabular}{|c|c|c|c|c|c|c|}
\hline \multirow[t]{2}{*}{ Biomass Type } & \multicolumn{5}{|c|}{$(\% \mathrm{~mol} / \mathrm{mol})$} & \multirow{2}{*}{$\begin{array}{c}\text { LHV } \\
\left(\mathrm{MJ} \cdot \mathrm{m}^{-3}\right)\end{array}$} \\
\hline & $\mathrm{H}_{2}$ & $\mathrm{CO}$ & $\mathrm{CO}_{2}$ & $\mathrm{CH}_{4}$ & $\mathbf{N}_{2}$ & \\
\hline Mixed wood & $19.7 \pm 1.9$ & $20.4 \pm 1.4$ & $18.9 \pm 1.0$ & $17.0 \pm 0.2$ & $23.5 \pm 1.3$ & $9.97 \pm 0.21$ \\
\hline Pinus & $19.1 \pm 1.8$ & $21.4 \pm 1.3$ & $20.4 \pm 1.6$ & $17.0 \pm 1.4$ & $21.0 \pm 1.8$ & $10.31 \pm 0.68$ \\
\hline $\begin{array}{l}\text { Plastic-coated } \\
\text { plywood }\end{array}$ & $24.8 \pm 1.9$ & $23.3 \pm 1.7$ & $20.7 \pm 1.2$ & $14.4 \pm 1.0$ & $14.7 \pm 1.3$ & $10.74 \pm 0.29$ \\
\hline Resin-coated plywood & $24.6 \pm 2.1$ & $21.8 \pm 1.6$ & $19.0 \pm 0.8$ & $13.1 \pm 0.6$ & $19.2 \pm 1.9$ & $10.28 \pm 0.26$ \\
\hline Weighted average ${ }^{1}$ & $20.7 \pm 2.7$ & $21.0 \pm 1.1$ & $19.3 \pm 0.8$ & $16.3 \pm 1.7$ & $21.6 \pm 2.2$ & $10.14 \pm 0.31$ \\
\hline
\end{tabular}

Tables 6-8 illustrate the results of the gaseous conversion for the four types of CCbiowaste studied. These tables show that the production of hydrogen, carbon monoxide, and methane varied with the gasification temperature. Taking into account the weighted average results, it is possible to observe that the percentage of carbon monoxide in the syngas increased by $61.5 \%$ from $700^{\circ} \mathrm{C}$ to $900{ }^{\circ} \mathrm{C}$, while there was a reduction in carbon dioxide percentage from $700^{\circ} \mathrm{C}$ to $900^{\circ} \mathrm{C}$. Additionally, the methane content increased with temperature, whilst there were reductions in the hydrogen and carbon dioxide contents in the syngas. Ruiz et al. (2013) stated that raising the temperature increases the concentration of $\mathrm{CO}$ and $\mathrm{H}_{2}$ in syngas and reduces that of $\mathrm{CO}_{2}, \mathrm{CH}_{4}$, and $\mathrm{H}_{2} \mathrm{O}$ [13]. However, similar behaviors were observed only for $\mathrm{CO}$ and $\mathrm{CO}_{2}$ using the CCbiowaste. In the CCbiowaste experiments, the production of $\mathrm{H}_{2}$ decreased and that of $\mathrm{CH}_{4}$ increased with temperature. These results can be modeled using the main gasification reactions that occur simultaneously inside the reactor. These reactions are char reactions, oxidation reactions, water-shift reactions, methanization reactions, and steam reactions [13].

Figures 2 and 3 illustrate the effect of temperature on the LHV and volume generation of gaseous fuels produced during gasification of the four types of biomass waste used from the construction site.

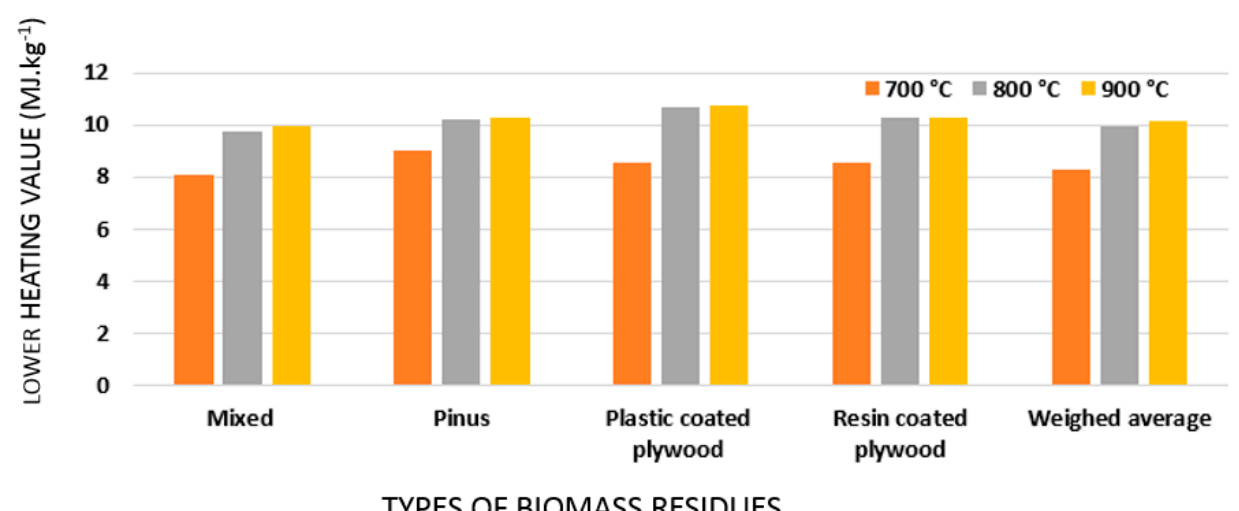

Figure 2. Effect of the gasification temperature on the LHV of the gaseous fuels.

The LHV results obtained in the CCbiowaste gasification at $700{ }^{\circ} \mathrm{C}, 800{ }^{\circ} \mathrm{C}$, and $900{ }^{\circ} \mathrm{C}$ ranged from 8.07 to $10.74 \mathrm{MJ} \cdot \mathrm{m}^{-3}$. These results were higher than those reported by Basu, Ruiz et al., Littlejohns et al., and Martinez et al., which ranged from 4.5-6.34 MJ. $\mathrm{m}^{-3}$ using several types of biomass such as wood chips, spruce, wood pallets, rice husk, sawdust, pine wood blocks, wood waste, and construction and demolition biomass, in temperatures ranging from $700{ }^{\circ} \mathrm{C}$ to $1000{ }^{\circ} \mathrm{C}[8,13,19,20]$. In this same temperature range, experiments using dried sugarcane bagasse obtained higher heating values ranging from 9.77 to $13.82 \mathrm{MJ} \cdot \mathrm{m}^{-3}[14,15]$. Passos et al. obtained results for the LHV of syngas at $8.62 \mathrm{MJ} \cdot \mathrm{m}^{-3}$, which was similar to that obtained at $700{ }^{\circ} \mathrm{C}$ using construction and demolition waste with $12.7 \%$ moisture (by mass) [10]. However, Passos et al. did not mention the temperature at which gasification was carried out. As mentioned by Littlejohns et al., there is a lack of experimental studies 
on CCbiowaste and landfill-diverted wood, which makes the comparison of results with other authors rather difficult, thus showing the originality of this work [19].

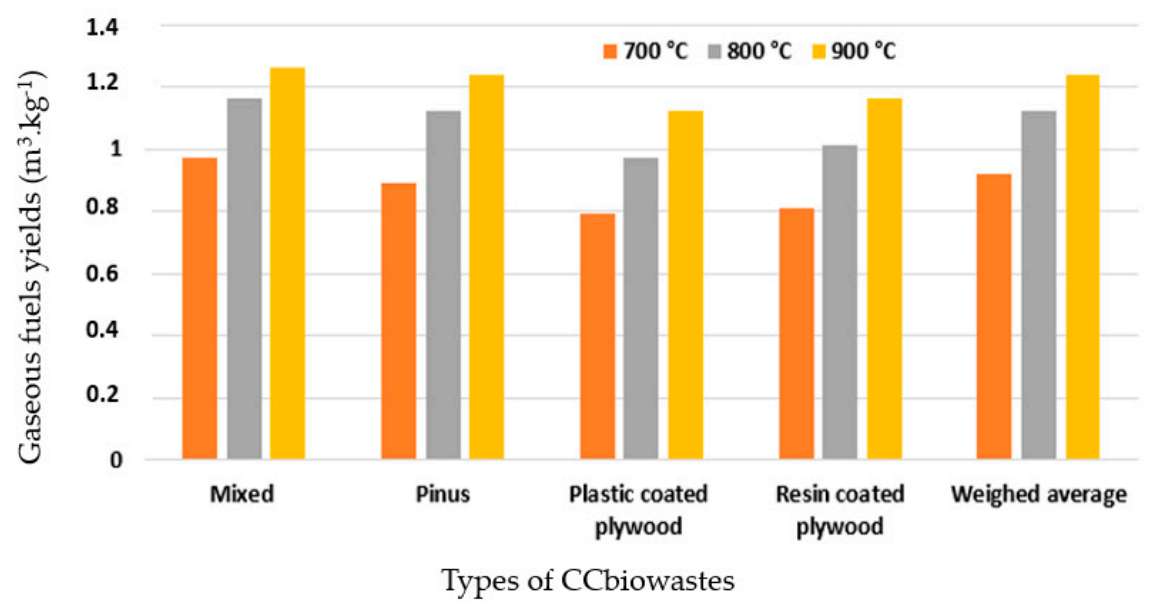

Figure 3. Effect of the gasification temperature on the gaseous fuel yields.

As shown in Figure 3, the gaseous fuel yields varied with temperature. Passos et al. reported a production of $0.916 \mathrm{Nm}^{3} \cdot \mathrm{kg}^{-1}$ in the gasification of $C \& D$ waste, similar to that produced with mixed wood [10]. Ruiz et al. stated that the amount of syngas produced per kilo of biomass varied from 2.2-2.4 $\mathrm{Nm}^{3} \cdot \mathrm{kg}^{-1}$ with pelletized biomass used in downdraft gasifiers [13]. Martinez et al. reported gaseous yields ranging from $1.62 \mathrm{Nm}^{3} \cdot \mathrm{kg}^{-1}$ for wood waste to $1.99 \mathrm{Nm}^{3} \cdot \mathrm{kg}^{-1}$ for sawdust and $1.44 \mathrm{Nm}^{3} \cdot \mathrm{kg}^{-1}$ for wood chips [20]. Arena et al. reported yields of 2.34 and $2.56 \mathrm{Nm}^{3} \cdot \mathrm{kg}^{-1}$ for solid recovered fuel (paper and plastic mixed solid fuel) at $880^{\circ} \mathrm{C}$ and $989^{\circ} \mathrm{C}$ gasification temperature, respectively [46].

Based on the results obtained for the LHV and gaseous fuel yields (Figures 2 and 3), it was possible to determine the total energy available (TEA) per ton of the four CCbiowaste types gasified at the given gasification temperatures $\left(700^{\circ} \mathrm{C}, 800{ }^{\circ} \mathrm{C}\right.$, and $\left.900{ }^{\circ} \mathrm{C}\right)$, as shown in Figure 4 .

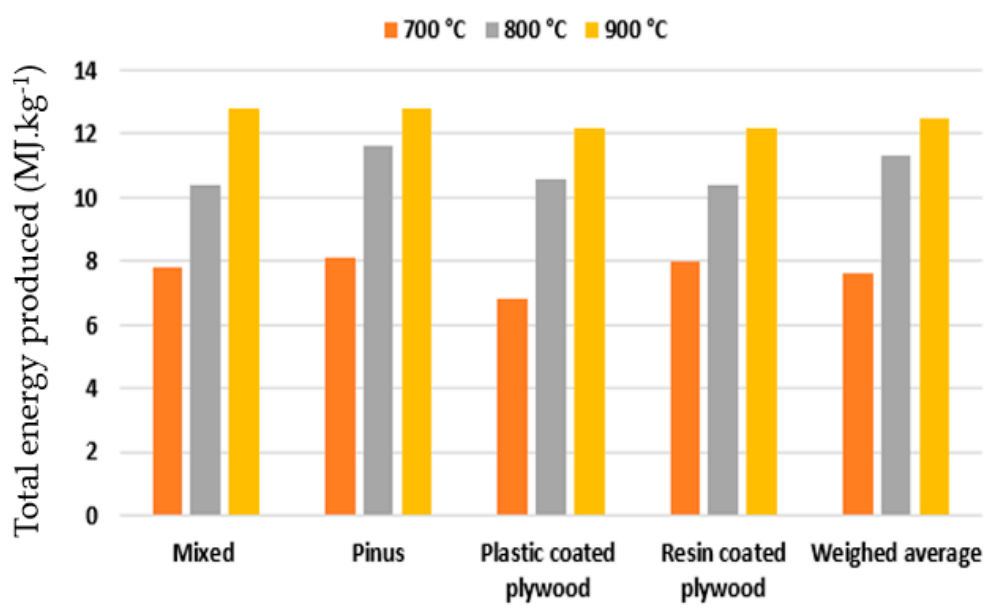

Types of CCbiowastes

Figure 4. Effect of temperature on the total energy available (TEA) (MJ.kg ${ }^{-1}$ ) of the gasified CCbiowaste.

Figure 4 illustrates that the total energy produced, in $\mathrm{MJ} \cdot \mathrm{kg}^{-1}$, increased significantly with temperature. This can be explained by the greater volume of gaseous fuels produced and the higher heating values, which increased with temperature. All four types of CCbiowaste studied presented similar behaviors. At $700{ }^{\circ} \mathrm{C}$, the total energy varied from 6.4 to $8 \mathrm{MJ} \cdot \mathrm{kg}^{-1}$; at $800^{\circ} \mathrm{C}$, the total energy 
was above $10 \mathrm{MJ} \cdot \mathrm{kg}^{-1}$ for all types of feedstock; at $900{ }^{\circ} \mathrm{C}$, the total energy reached values above $12 \mathrm{MJ} \cdot \mathrm{kg}^{-1}$.

It was not possible to find the TEA for wood waste or C\&D waste in the literature, even though some authors reported values of the LHV $\left(\mathrm{MJ} \cdot \mathrm{m}^{-3}\right)$ and yield $\left(\mathrm{Nm}^{3} \cdot \mathrm{kg}^{-1}\right)[10,13,20,46]$. To enable a comparison with the CCbiowaste TEA, the authors multiplied the values of LHV and gaseous yield using the values found in the literature to determine the TEA of several types of biomass, as shown in Table $9[10,14,15,20,46]$.

Table 9. TEA calculation for biomass gasification.

\begin{tabular}{|c|c|c|c|c|c|}
\hline Biomass & $\begin{array}{c}\text { Temperature } \\
\left({ }^{\circ} \mathrm{C}\right)\end{array}$ & $\begin{array}{c}\text { Yields } \\
\left(\mathrm{Nm}^{3} \cdot \mathrm{kg}^{-1}\right)\end{array}$ & $\begin{array}{c}\text { LHV } \\
\left(\mathrm{MJ} \cdot \mathrm{m}^{-3}\right)\end{array}$ & $\begin{array}{c}\text { TEA * } \\
\left(\mathrm{MJ} \cdot \mathrm{kg}^{-1}\right)\end{array}$ & Reference \\
\hline C\&D waste & n.a. & 0.916 & 8.62 & 7.90 & [10] \\
\hline Sugarcane bagasse & 900 & 0.55 & 12.25 & 6.74 & {$[14,15]$} \\
\hline Sugarcane bagasse & 1000 & 0.65 & 12.84 & 8.35 & {$[14,15]$} \\
\hline Wood chips & n.a. & 1.44 & 5.06 & 7.29 & {$[20]$} \\
\hline Sawdust & 900 & 1.99 & 6.32 & 12.58 & [20] \\
\hline Wood waste & 1050 & 1.62 & 6.34 & 10.27 & [20] \\
\hline Hazelnut shells & 1025 & 1.97 & 4.55 & 8.96 & [20] \\
\hline Solid recovered fuel (SRF) & 800 & 2.34 & 5.16 & 12.07 & [46] \\
\hline Solid recovered fuel (SRF) & 898 & 2.56 & 4.91 & 12.57 & [46] \\
\hline
\end{tabular}

C\&D—construction and demolition; n.a.-not available; ${ }^{*}$ calculated by the authors.

Hence, when analyzing the TEA for the different types of CCbiowaste with respect to the values in Table 9, it is possible to verify that the values obtained at $700{ }^{\circ} \mathrm{C}$ gasification were closer to those for sugarcane bagasse at $900^{\circ} \mathrm{C}$, wood chips, and C\&D waste. For the CCbiowaste gasification at $800^{\circ} \mathrm{C}$, the results were similar to those for wood waste at $1050^{\circ} \mathrm{C}$ (much higher temperature). The best results for CCbiowaste gasification were obtained at the gasification temperature of $900{ }^{\circ} \mathrm{C}$. The TEA results varied from 12 to $12.8 \mathrm{MJ} \cdot \mathrm{kg}^{-1}$ which were similar to the TEA results for solid recovered fuel (SRF) and sawdust. This means that the use of CCbiowaste as a feedstock for gasification processes is very promising, and it is a good way to valorize the biomass waste generated at construction sites, as well as significantly reduce the environmental impact.

\subsection{Energy Production and the Brazilian ProGD}

If we considered that the 200 tons of construction wood wasted daily in Recife is used for power production, this would generate 6400 MWh monthly. As mentioned, the Brazilian ProGD program established values to purchase the electricity generated using residual biomass as R $\$ 349.00 / \mathrm{MWh}$ (USD \$85.5287/MWh) and that using municipal solid waste as R\$561.00 (USD \$137.48315) [18,19]. Hence, the electricity generated can be sold to power companies through the Brazilian ProGD Program. This would generate a revenue of $R \$ 2,233,600.00$ (USD $\$ 547,383.90$ ) per month if the CCbiowaste or landfill-derived fuel is used as a feedstock in Recife, Brazil. This revenue may attract power and civil construction companies to invest in such technology to produce electricity.

Hence, the gasification of wasted biomass from construction sites and its use as a fuel for power generation in internal combustion engines (Otto cycle engines) seems to be an interesting solution to valorize the biomass waste while providing electricity and reducing or even eliminating the environmental problems caused by the dumping of biomass.

\section{Conclusions}

CCbiowaste can be used as a feedstock for the gasification process to generate electricity. If all 200 tons of construction wood wasted daily in Recife is used for power production, this would generate 6400 MWh monthly, which may have a revenue of R\$2,233,600.00 (USD \$547,383.90) per month, and which may attract investors to use this technology. 
Gasification produced gaseous fuels with an average LHV ranging from $8.28 \mathrm{MJ} \cdot \mathrm{m}^{-3}$ for experiments carried out at $700{ }^{\circ} \mathrm{C}$ to $9.95 \mathrm{MJ} \cdot \mathrm{m}^{-3}$ at $800{ }^{\circ} \mathrm{C}$ and $10.14 \mathrm{MJ} \cdot \mathrm{m}^{-3}$ at $900{ }^{\circ} \mathrm{C}$.

The best energy results were obtained when gasifying CCbiowaste at $900{ }^{\circ} \mathrm{C}$, with values above $12 \mathrm{GJ} \cdot$ ton $^{-1}$.

Among the different types of CCbiowaste studied, the best results were obtained for mixed wood and Pinus at $900{ }^{\circ} \mathrm{C}$, with values of approximately $13 \mathrm{GJ} \cdot$ ton $^{-1}$.

The use of gasification could be an interesting way to valorize CCbiowaste, while providing sustainable electricity and reducing (or even eliminating) the environmental problems caused by the dumping of biomass in landfills, where it does not degrade significantly.

Author Contributions: S.P. designed the experiments, discussed the results, and prepared the original paper; A.G. helped with the data on construction biomass waste and analyzed the results; F.V.eS., H.S., and E.L. managed the experimental tests. All authors helped in discussing the results and formatting the paper. All authors have read and agreed to the published version of the manuscript.

Funding: The authors would like to thank AES Tiete and ANEEL for the R\&D funding support to develop this research, the POLICOM team that helped in setting up the experiments and provided analytical equipment, and the University of Pernambuco for the incentive and support.

Conflicts of Interest: The authors declare no conflicts of interest.

\section{References}

1. Vanderlei e Silva, F.M. Potencial Energético dos Resíduos de Biomassa Oriundos da Construção Civil. Master's Thesis, University of Pernambuco, Recife, PE, Brazil, 2014.

2. Ximenes, F.; Björdal, C.; Cowie, A.; Barlaz, M. The decay of wood in landfills in contrasting climates in Australia. Waste Manag. 2015, 41, 101-110. [CrossRef] [PubMed]

3. Carpenter, A.; Jambeck, J.R.; Gardner, K.; Weitz, K. Life Cycle assessment of end-of-life management options for construction and demolition debris. J. Ind. Ecol. 2012, 17, 396-406. [CrossRef]

4. Diyamandoglu, V.; Fortuna, L.M. Deconstruction of wood-framed houses: Material recovery and environmental impact. Resour. Conserv. Recycl. 2015, 100, 21-30. [CrossRef]

5. Wang, X.; Padgett, J.M.; De la Cruz, F.B.; Barlaz, M.A. Wood biodegradation in laboratory-scale landfills. Environ. Sci. Technol. 2011, 45, 6864-6871. [CrossRef] [PubMed]

6. Ximenes, F.A.; Gardner, W.D.; Cowie, A.L. The decomposition of wood products in landfills in Sydney, Australia. Waste Manag. 2008, 28, 2344-2354. [CrossRef] [PubMed]

7. Khan, M.U.; Ahring, B.K. Lignin degradation under anaerobic digestion: Influence of lignin modifications-A review. Biomass Bioenergy 2019, 128, 105325. [CrossRef]

8. Badu, P. Biomass Gasification and Pyrolysis: Practical Design and Theory; Academic Press: Burlington, MA, USA, 2010; p. 365. ISBN 978-0-12-374988-8.

9. Buendia-Kandia, F.; Brosse, N.; Petitjean, D.; Mauviel, G.; Rondags, E.; Guedon, E.; Dufour, A. Hydrothermal conversion of wood, organosolv, and chlorite pulps. Biomass Convers. Biorefinery 2019. [CrossRef]

10. Passos, J.; Alves, O.; Brito, P. Management of municipal and construction and demolition wastes in Portugal: Future perspectives through gasification for energetic valorisation. Int. J. Environ. Sci. Technol. 2020. [CrossRef]

11. Toor, S.S.; Rosendahl, L.; Rudolf, A. Hydrothermal liquefaction of biomass: A review of subcritical water technologies. Energy 2011, 36, 2328-2342. [CrossRef]

12. Gumisiriza, R.; Hawumba, J.F.; Okure, M.; Hensel, O. Biomass waste-to-energy valorization technologies: A review case for banana processing in Uganda. Biotechnol. Biofuels 2017, 10, 11. [CrossRef]

13. Ruiz, J.A.; Juárez, M.C.; Morales, M.P.; Muñoz, P.; Mendívil, M.A. Biomass gasification for electricity generation: Review of current technology barriers. Renew. Sustain. Energy Rev. 2013, 18, 174-183. [CrossRef]

14. Peres, S. Catalytic Indirectly Heated Gasification of Bagasse. Ph.D. Thesis, University of Florida, Gainesville, FL, USA, 1997.

15. Peres, S.; Green, A. Catalytic Indirectly Heated Gasification of Bagasse. In Proceedings of the ASME 1998 International Gas Turbine and Aeroengine Congress and Exhibition, Stockholm, Sweden, 2-5 June 1998. [CrossRef] 
16. Samiran, N.A.; Jaafar, M.N.M.; Ng, J.; Lam, S.S.; Chong, C.T. Progress in biomass gasification technique-With focus on Malaysian palm biomass for syngas production. Renew. Sustain. Energy Rev. 2016, 62, 1047-1062. [CrossRef]

17. Sikarwar, V.S.; Zhao, M.; Clough, P.; Zhong, X.; Memon, M.Z.; Shah, N.; Anthony, E.J.; Fennel, P.S. An overview of advances in biomass gasification. Energy Environ. Sci. 2016, 9, 2939-2977. [CrossRef]

18. Kirubakaran, V.; Sivaramakrishnan, V.; Nalini, R.; Sekar, T.; Premalatha, M.; Subramanian, P. A review on gasification of biomass. Renew. Sustain. Energy Rev. 2009, 13, 179-186. [CrossRef]

19. Littlejonhs, J.V.; Butler, J.; Luque, L.; Austin, K. Experimental investigation of bioenergy production from small-scale gasification of landfill-diverted wood wastes. Waste Biomass Valorization 2020. [CrossRef]

20. Martínez, J.D.; Mahkamov, K.; Andrade, R.V.; Lora, E.E.S. Syngas production in downdraft biomass gasifiers and its application using internal combustion engines. Renew. Energy 2012, 38, 1-9. [CrossRef]

21. Peres, S. Uso da Fração Orgânica dos Resíduos Sólidos Urbanos em Biodigestores para Produção de Biogás e Geração Descentralizada de Energia Elétrica em Pernambuco. Ph.D. Thesis, Universidade de Pernambuco, Recife, PE, Brazil, 2018.

22. MME. Ministério de Minas e Energia. Programa de Desenvolvimento da Geração Distribuída de Energia Elétrica-PROGD. Portaria 65, de 27 de Fevereiro de 2018. Available online: http://www.lex.com.br/legis_ 27619397_PORTARIA_N_65_DE_27_DE_FEVEREIRO_DE_2018.aspx (accessed on 20 December 2019).

23. Banco Central do Brasil. Taxa de Venda do Dólar (USD to Brazilian Real Exchange Rate). Available online: https://www.bcb.gov.br/estabilidadefinanceira/fechamentodolar (accessed on 27 December 2019).

24. Parsekian, G.A.; Medeiros, W.A.; Sipp, G. High-rise concrete and clayblock masonry building in Brazil. Mauerwerk 2018, 22, 260-272. [CrossRef]

25. ABNT NBR 10.007:2004. Sampling of Solid Waste; Brazilian Standard: Rio de Janeiro Centro, Brazil, 2004; Available online: https://www.abntcatalogo.com.br/ (accessed on 28 December 2019).

26. ABNT NBR 7190:1997. Design of Wooden Structures; Brazilian Standard: Rio de Janeiro Centro, Brazil, 1997; Available online: https://www.abntcatalogo.com.br/ (accessed on 28 December 2019).

27. ABNT NBR 14929. Determination of Moisture of Chips-Method by Drying in Oven-Dried; Brazilian Standard: Rio de Janeiro Centro, Brazil, 2003; Available online: https://www.abntcatalogo.com.br/ (accessed on 28 December 2019).

28. ASTM D4442-07. Standard Test Methods for Direct Moisture Content Measurement of Wood and Wood-Based Materials; United States Standard, 2007; Available online: https:/webstore.ansi.org/sdo/astm?gclid= EAIaIQobChMIh6ykm4ze6AIVC5-fCh2MQAi-EAAYASABEgLBXfD_BwE (accessed on 28 December 2019).

29. ASTM D3176-15. Standard Method for Ultimate Analysis of Coal and Coke; United States Standard, 2015; Available online: https://webstore.ansi.org/sdo/astm?gclid=EAIaIQobChMIh6ykm4ze6AIVC5-fCh2MQAiEAAYASABEgLBXfD_BwE (accessed on 28 December 2019).

30. ASTM D3172-12 (2008). Standard Method for Ash in the Analysis Sample of Coal and Coke from Coal; United States Standard, 2008; Available online: https://webstore.ansi.org/sdo/astm?gclid=EAIaIQobChMIh6ykm4ze6AIVC5fCh2MQAi-EAAYASABEgLBXfD_BwE (accessed on 28 December 2019).

31. ABNT NBR 8289. Carvão Mineral—Determinação do Teor de Cinzas; 1983 Rio de Janeiro Centro - RJ - 20031-901, Brazil; 2003; Available online: https://www.abntcatalogo.com.br/ (accessed on 28 December 2019).

32. ASTM D2974-87. Standard Test Methods for Moisture, Ash, and Organic Matter of Peat and Other Organic Soils; United States Standard, 1987; Available online: https://webstore.ansi.org/sdo/astm?gclid= EAIaIQobChMIh6ykm4ze6AIVC5-fCh2MQAi-EAAYASABEgLBXfD_BwE (accessed on 28 December 2019).

33. ASTM D2015-77. Standard Methods Method for Gross Calorific Value of Coal and Coke by the Adiabatic Bomb Calorimeter; United States Standard, 1977; Available online: https://webstore.ansi.org/sdo/astm?gclid= EAIaIQobChMIh6ykm4ze6AIVC5-fCh2MQAi-EAAYASABEgLBXfD_BwE (accessed on 28 December 2019).

34. Cavalcanti, S.J.L. Estudo do Potencial Energético do Caroço de Manga via Gaseificação. Master's Thesis, Universidade de Pernambuco, Recife, PE, Brazil, 2017.

35. Geraldo, B.C.A. Gaseificação da Casca e Torta da Mamona para Produção de gás Combustível. Master's Thesis, Universidade Federal de Pernambuco, Recife, PE, Brazil, 2012.

36. Zenid, G.J. Madeira: Uso Sustentável na Construção Civil, 2nd ed.; Instituto de Pesquisas Tecnológicas: São Paulo, Brazil, 2009; Available online: https://www.ipt.br/centros_tecnologicos/CT-FLORESTA/livros/3-madeira: _uso_sustentavel_na_construcao_civil.htm (accessed on 26 February 2020). 
37. Mello, F.S.; Vieira, G.G. Aproveitamento dos resíduos sólidos de madeira da construção civil, para geração de energia alternativa. Bioenergia Rev. Diálogos 2015, 5, 46-57.

38. Francescato, V.; Antonini, E.; Bergomi, L.Z.; Metschina, C.; Schnedl, C.; Krajnc, N.; Koscik, K.; Gradziuk, P.; Nocentini, G.; Stranieri, S. Wood Fuels Handbook; AIEL-Italian Agriforestry Energy Association: Legnaro (Pd), Italy, 2008; pp. 1-83.

39. Reed, T.B.; Gaur, S. An Atlas of Thermal Data for Biomass and Other Fuels, 2nd ed.; The Biomass Energy Foundation Press: Franktown, CO, USA, 2009; pp. 1-290.

40. Arias, B.; Pevida, C.; Fermoso, J.; Plaza, M.G.; Rubiera, F.; Pis, J.J. Influence of torrefaction on the grindability and reactivity of woody biomass. Fuel Process. Technol. 2008, 89, 169-175. [CrossRef]

41. Álvarez-Álvarez, P.; Pizarro, C.; Barrio-Anta, M.; Cámara-Obregón, A.; Bueno, J.L.M.; Álvarez, A.; Gutiérrez, I.; Burslem, D.F.R.P. Evaluation of tree species for biomass energy production in northwest Spain. Forests 2018, 9, 160. [CrossRef]

42. Pinto, F.; Gominho, J.; André, R.N.; Gonçalves, D.; Miranda, M.; Varela, F.; Neves, D.; Santos, J.; Lourenço, A.; Pereira, H. Improvement of gasification performance of Eucalyptus globulus stumps with torrefaction and densification pre-treatments. Fuel 2017, 206, 289-299. [CrossRef]

43. Wang, G.; Zhang, J.; Shao, J.; Liu, Z.; Zhang, G.; Xu, T.; Guo, J.; Wang, H.; Xu, R.; Lin, H. Thermal behavior and kinetic analysis of co-combustion of waste biomass/low rank coal blends. Energy Convers. Manag. 2016, 124, 414-426. [CrossRef]

44. Pintor-Ibarra, L.F.; Carrillo-Parra, A.; Herrera-Bucio, R.; López-Albarrán, P.; Rutiaga-Quiñones, J.G. Physical and Chemical properties of timber by-products from Pinus Leiophylla, P. Montezumae and P. Pseudostrobus for a bioenergetic use. Wood Res. 2017, 62, 849-862.

45. Raj, T.; Kapoor, M.; Gaur, R.; Christopher, J.; Lamba, B.Y.; Tuli, D.K.; Kumar, R. Physical and chemical characterization of various Indian agriculture residues for biofuels production. Energy Fuels 2015, 29, 3111-3118. [CrossRef]

46. Arena, U.; Gregorio, F.D.; Troia, G.D.; Saponaro, A. A techno-economic evaluation of a small-scale fluidized be gasifier for solid recovered fuel. Fuel Process. Technol. 2015, 131, 69-77. [CrossRef]

(C) 2020 by the authors. Licensee MDPI, Basel, Switzerland. This article is an open access article distributed under the terms and conditions of the Creative Commons Attribution (CC BY) license (http://creativecommons.org/licenses/by/4.0/). 